Vol. 7, No. 3, 2019, pp. 123-130

DOI: https://doi.org/10.29210/138700

Contents lists available at Jurnal IICET

Jurnal Konseling dan Pendidikan

ISSN: 2337-6740 (Print) ISSN: 2337-6880 (Electronic)

Journal homepage: http://jurnal.konselingindonesia.com

\title{
Manajemen kebijakan kepala madrasah dalam meningkatkan mutu pendidikan
}

\author{
Murni Yanto ${ }^{1}$, Irwan Fathurrochman ${ }^{2}$ \\ ${ }^{12}$ Institut Agama Islam Negeri Curup
}

\begin{tabular}{|c|c|}
\hline Article Info & ABSTRACT \\
\hline Article history: & This qualitative research raises the theme of Madrasah Head Policy \\
\hline Received Aug $16^{\text {th }}, 2019$ & Management in improving the quality of education in Madrasah Ibtidaiyah \\
\hline Revised Oct 26 $6^{\text {th }}, 2019$ & Negeri 1 Rejang Lebong, the results of the study indicate that the quality of \\
\hline Accepted Dec 30 ${ }^{\text {th }}, 2019$ & $\begin{array}{l}\text { education can be achieved by prioritizing madrasas in curriculum } \\
\text { development and teacher professional development through the activities of } \\
\text { Teacher Working Groups, Madrasah Head Policy Management can be }\end{array}$ \\
\hline Keyword: & done through internal and external factors of madrasas in fostering teacher \\
\hline Management & honesty, appreciation, harmonious and humane climate of communication \\
\hline Madrasah head policy & of democracy between leaders and teachers, Principals of madrasas foster a \\
\hline Quality of education & $\begin{array}{l}\text { conducive atmosphere of madrasah, foster a sense of responsibility to } \\
\text { teachers in teaching, through coordination with district leaders, madrasa } \\
\text { committee and the community, so that the quality of education can be } \\
\text { improved. }\end{array}$ \\
\hline
\end{tabular}

Corresponding Author:

Murni Yanto

Email: yantomurni.65@gmail.com

\section{Pendahuluan}

Kepala madrasah sebagai pemimpin pendidikan harus dapat mengenal dan mengerti berbagai kedudukan, keadaan dan apa yang diinginkan baik oleh guru maupun pegawai tata usaha serta pembantu lainnya (Hou et al., 2018). Sehingga dengan adanya kerjasama yang baik dapat menghasilkan pikiran yang harmonis dalam usaha perbaikan madrasah (Sadler, 2017). Kepala madrasah merupakan motor penggerak penentu arah kebijakan madrasah, yang akan menentukan bagaimana tujuan madrasah dan pendidikan pada umumnya direalisasikan (Beerkens, 2018; Davis, 2017). Kepala madrasah dituntut untuk senantiasa meningkatkan efektifitas kinerja sehingga dapat memberikan hasil yang memuaskan (Hidayat \& Machali, 2018; Manap, 2013). Mutu pendidikan bukanlah suatu yang berdiri sendiri tetapi merupakan suatu kesatuan yang saling berhubungan dan terkait sebagai suatu proses dalam sebuah sistem, bila membicarakanmasalah mutu pendidikan maka tidak akan terlepas dari tiga unsur pendidikan yaitu, input, proses, dan lulusan (Amin, Arsil, Fathurrochman, Bahri, \& Rahmaningsih, 2019; Pretorius \& Macaulay, 2019; Ristianti, Danim, Winarto, \& Dharmayana, 2019).

Dalam Undang-Undang 1945 pasal 31 : Setiap warga Negara berhak mendapatkan pendidikan. Landasan konstitusional komitmen pendidikan inilah yang membuka peluang yang sebesar-besarnya bagi bangsa Indonesia untuk berbuat baik bagi sistem pendidikan nasional melalui berbagai kebijakan bidang pemerintahan dan pembangunan, termasuk kebijakan otonomi daerah. Kepala madrasah harus mampu melahirkan gagasan inovatif yang berguna untuk menghasilkan alternatif kebijakan dalam membangun (Hidayat \& Machali, 2018). Sistem pendidikan yang efisien, bermutu dan sesuai dengan kebutuhan masyarakat dalam berbagai bidang kehidupan (Salto, 2018). 
Menurut (Davis, 2017) lembaga pendidikan merupakan sumber daya manusia yang menjadi subjek dan objek pembangunan yang perlu ditingkatkan mutunya melalui jalur pendidikan dalam fungsi, proses, dan aktifitasnya yang bermuara pada pencapaian tujuan pendidikan nasional (Khasanah, 2014).

Madrasah Ibtidaiyah Negeri (MIN) Rejang Lebong bagi masyarakat adalah untuk mendapatkan pendidikan yang bermutu dengan harapan menjadi alternatif bagi masyarakat untuk mendapatkan pendidikan yang baik bagi anak-anaknya dari segi akademis maupun non akademis. Sebagai pendidikan formal MIN 1 Rejang Lebong mempunyai potensi untuk berkembang sebagai lembaga pendidikan yang mampu bersaing dengan lembaga pendidikan lainnya. Dalam perkembangan mutu pendidikan MIN 1 Rejang Lebong patut dibanggakan, karena merupakan salah satu madrasah yang ingin menjadi madrasah yang bermutu.

\section{Metode}

Sugiyono (2017) mendefiniskan bahwa penelitian kualitatif merupakan hal yang dapat dilakukan dalam penelitian ilmu-ilmu sosial, oleh karena itu penelitian ini menggunakan metode kualitatif, dimana penelitian digunakan untuk meneliti kondisi obyek yang alamiah (Istiningtyas \& Lukmawati, 2019; Rusandi, Sugiharto, \& Sunawan, 2019). Pengumpulan data dilakukan secara gabungan atau simultan melalui proses pertanyaan, analisis, dan mengkonstruksi sosial sehingga hasil penelitian menjadi jelas dan bermakna (Fitri et al., 2018; Ristianti et al., 2019; Rusandi et al., 2019) menjelaskan bahwa dalam penelitian kualitatif peneliti berperan langsung sebagai instrumen penelitian, sehingga data penelitian tentang Kebijakan Kepala Sekolanh ini dapat terkumpul dengan baik dan dapat diolah menjadi hasil penelitian yang mampu menggambarkan obyek penelitian secara alami (Fathurrochman, Budiman, Alamsyahril, \& Kristiawan, 2019; Kristiawan, 2016; Murfi, 2014).

\section{Hasil Penelitian, Diskusi dan Pembahasan}

\section{Kebijakan Pendidikan}

Kebijakan (policy) secara etimologi diturunkan dari bahasa Yunani yaitu "polis" yang artinya kota. Analisis kebijakan pendidikan dapat dipahami baik melalui pendekatan metodologis maupun konseptual. Metodologi pada intinya merupakan keseluruhan proses yang secara sistematis dilakukan untuk melembagakan kebijakan dalam suatu sistem dan mekanisme yang institusional (Torabi et al., 2016). Secara konseptual analisis kebijakan merupakan suatu ilmu perekayasaan sosial (social engineering) yang artinya ialah ilmu yang ditujukan untuk melahirkan manfaat dari konsep dan teori dalam berbagai disiplin ilmu sosial untuk pemecahkan permasalahan yang dihadapi oleh suatu kebijakan publik.

Kebijakan pendidikan merupakan salah satu kebijakan publik. Kebijakan publik merupakan kebijakan yang menyangkut masyarakat umum. Kebijakan publik merupakan bagian dari keputusan politik, dimana keputusan tersebut menyangkut dan mempengaruhi masyarakat serta di fahami sebagai pilihan terbaik dari berbagai alternatif pilihan mengenai urusan publik yang menjadi kewenangan pemerintah (Kusumawati, 2019).

Berdasarkan dari uraian di atas dapat disimpulkan bahwa: kebijakan pendidikan merupakan keseluruhan proses dan hasil perumusan langkahlangkah strategis pendidikan yang dijabarkan dari visi, misi pendidikan dalam rangka untuk mewujudkan tercapainya tujuan pendidikan dalam suatu masyarakat untuk suatu kurun waktu tertentu (Ramdhani \& Ramdhani, 2017).

Menurut Nurharjatmo, dengan modelnya merumuskan sejumlah faktor yang mempengaruhi kinerja kebijakan adalah; 1) standar dan sasaran tertentu yang harus dicapai oleh para pelaksana kebijakan, 2) tersedianya sumber daya, baik yang berupa dana, tehnologi, sarana maupun prasarana lainnya, 3) komunikasi antara organisasi yang baik ,4) karakteristik birokrasi pelaksana, 5) kondisi sosial, ekonomi, dan politik (Amin et al., 2019).

Ada beberapa aspek yang tercakup dalam kebijakan pendidikan, diantaranya adalah: 1. Kebijakan pendidikan dilahirkan dari kesatuan teori dan praktik 2. Kebijakan pendidikan mempunyai validitas perkembangan pribadi serta masyarakat yang memiliki pendidikan itu 3. Kebijakan pendidikan ditujukan pada kebutuhan peserta didik 4. Kebijakan pendidikan berkaitan dengan penjabaran visi, misi dan tujuan 
pendidikan 5. Kebijakan pendidikan memiliki kejelasan tujuan untuk melahirkan pendidikan yang tepat (Irmayani, Wardiah, \& Kristiawan., 2018).

Kebijakan pendidikan adalah suatu bentuk tindakan yang diambil atas beberapa pertimbangan, untuk mengarahkan manajer/kepala madrasah dalam menentukan masa depan madrasah sesuai dengan visi, misi pendidikan agar tercapai tujuan pendidikan yang diinginkan (Mardlotillah, 2013).

\section{Fungsi dan tujuan kebijakan pendidikan}

Faktor yang menentukan perubahan, pengembangan, atau reskontruksi organisasi adalah terlaksananya kebijakan organisasi sehingga dapat dirasakan bahwa kebijakan tersebut benar-benar berfungsi dengan baik. Dengan demikian dapat disimpulkan bahwa kebijakan dibuat untuk menjadi pedoman dalam bertindak, mengarahkan kegiatan dalam organisasi untuk mencapai tujuan yang telah ditetapkan. Fungsi kebijakan kedalam tiga bagian pokok, yaitu :

Pertama; Fungsi alokasi. Untuk melaksanakan fungsi penting ini analisis kebijakan harus mampu melibatkan diri didalam, atau paling tidak mempelajari tentang sistem, dan proses pembuatan kebijakan negara baik pada tingkat suprastruktur (political) maupun pada tingkatan sektoral (teknichal).

Kedua; Fungsi inquiri. Fungsi inquiri dapat dilakukan jika seluruh atau sebagian agenda penelitian dan pengembangan sudah dilaksanakan dan mencapai hasil-hasilnya. Dalam fungsi inquiri pelaksanaan analisis kebijakan berkaitan dengan pendekatan, metodologi, serta teknik-teknik analisis.

Ketiga; Fungsi komunikasi, yaitu fungsi yang dapat dilaksanakan jika analisis kebijakan menghasilkan berbagai gagasan atau usulan kebijakan yang benar-benar realistis (Noor \& Sikand, 2008).

Kebijakan jangka panjang (periode 25 tahun), adalah Kebijakan jangka panjang pada dasarnya merupakan suatu kebijakan yang bersifat prospektif (antisipasi masa depan), yaitu kebijakan negara dibidang pendidikan yang ditentukan oleh suatu proyeksi pendidikan dalam suatu cakupan waktu kedepan. Perencanaan ini dimaksudkan untuk menghasilkan skenario masa depan pendidikan dan kebudayaan di Indonesia yang perlu diciptakan pada akhir kurun waktu pembangunan jangka panjang kedua (Fathurrochman, 2017; Ngalim, 2007).

Kebijakan jangka menengah, Secara umum gambaran repelita: a). Arah dan kebijakan repelita. b). Keadaan dan masalah, masalah-masalah pokok yang disimpulkan dari keadaan pendidikan sebagai hasil dari penilaian dan kajian pelaksanaan pendidikan dalam repelita sebelumnya. c). Kebijaksanaan dan langkah-langkah, Kebijakan ini dikembangkan berdasarkan analisis terhadap keadaan masalah pendidikan sekarang dan perkiraan dalam lima tahun mendatang. d). Program dan sasaran, jika kebijakan yang dirumuskan diatas telah dilaksanakan (Pemerintah Republik Indonesia, 2005).

Kebijakan jangka pendek, Dalam perencanaan tahunan, meliputi empat periode dengan lama tiga bulan untuk tiap periode yang dapat dijelaskan sebagai berikut: Pertama, tahap persiapan perencanaan, tahap ini merupakan penyiapan data khususnya syang berkaitan dengan jumlah peserta didik yang akan dilayani, kepegawaian, sarana dan prasarana yang diperlakukan serta peralatan yang dibutuhkan. Kedua, periode ini merupakan waktu untuk merumuskan dan mempublikasikan kebijakan. Ketiga, urusan proyek dan penetapan pagu anggaran. Periode untuk melaksanakan usulan anggaran proyek Keempat, dalam periode ini persiapan pelaksanaan proyek pembangunan telah dilaksanakan dan persiapan untuk siklus perencanaan tahun berikutnya mulai dirintis dan dilaksanakan (Pemerintah Republik Indonesia, 2005).

\section{Komponen kebijakan}

Kebijakan yang diterapkan oleh pemerintah memiliki beberapa komponen yang dapat di rumuskan menajdi sebagaimana beriktu ini ; (a). perumusan masalah; perumusan masalah dapat membantu menemukan asumsi-asumsi yang tersembunyi, media, memetakan tujuan-tujuan yang memungkinkan, memadukan pandangan-pandangan yang bertentangan, dan merancang kebijakan-kebijakan yang baru. (b). peramalan; peramalan dapat menyediakan pengetahuan yang relevan dengan kebijakan tentang masalah yang akan terjadi dimasa mendatang: (1) Proyeksi adalah ramalan yang didasarkan pada ekstrapolasi atas kecenderungan masa lalu maupun masa kini ke masa depan, (2) Sebuah prediksi adalah ramalan yang didasarkan pada asumsi teoritik yang tegas. (3) Suatu perkiraan adalah ramalan yang didasarkan pada penilaian yang informative atau penilaian pakar tentang situasi masyarakat dimasa depan. (c). rekomendasi; rekomendasi kebijakan adalah cara yang dilaksanakan agar sebuah kebijakan apat mencapai sasarannya. Dalam rekomendasi kebijakan maka yang perlu diperhatikan adalah bagaimana prakondisi untuk keberhasilan pelaksanaan kebijakan. (d) Pemantauan ; pemantauan 
merupakan prosedur analisis kebijakan yang digunakan untuk memberikan informasi tentang sebab dan akibat dari kebijakan publik. (e). evaluasi; evaluasi membuahkan pengetahuan yang relevan dengan kebijakan tentang ketidaksesuaian antara kinerja kebijakan yang diharapkan dengan yang dihasilkan.

\section{Mutu Pendidikan}

Mutu adalah pemenuhan terhadap kebutuhan stakeholde, bersistem pencegahan, mempunyai standar tanpa cacat dan mempunyai ukuran harga ketidakpuasan. Mutu dalam bidang pendidikan meliputi mutu input, output dan outcomes. Input pendidikan dinyatakan bermutu jika siap berproses, proses pendidikan bermutu apabila mampu menciptakan suasana yang pendidikan aktif, inovatif, kreatif, efektif dan menyenangkan. Output pendidikan dikatakan bermutu jika hasil belajar akademik maupun non akademik siswa tinggi. Outcome dinyatakan bermutu apabila lulusan terserap di dunia kerja, gaji wajar, semua pihak mengakui kehebatan lulusan dan merasa puas (Akinyemi \& Abiddin, 2013; Beerkens, 2018).

Menurut (Pfeffer, 2015) ada beberapa kebingungan terhadap pemaknaan mutu bisa muncul karena mutu dapat digunakan sebagai konsep yang secara bersama-sama absolute dan relative. Mutu secara mutlak atau absolut memiliki ukuran nilai tertinggi, bersifat unik dan sangat berkaitan dengan ungkapan kebaikan (goodness), keindahan (beauty), kebenaran (truth) dan idealitas. Biasanya mutu dalam ukuran absolut sudah ditetapkan produsen secara subjektif.

Aplikasi mutu yaitu: pertama redefinisi tugas untuk memudahkan kerja bagi semua unsur pendidikan, maka diperlukan pembagian tugas (job description) yang jelas. Sekaligus sebagai upaya menghindari dari overlapping diantara masing-masing unsur tersebut.Kedua, prefisionalisme pimpinan lembaga pendidikan yang paling bertanggung jawab dalam tumbuh kembangnya prakarsa, partisipasi, inovasi dan kreatifitas dalam pengembangan kelembagaan. Ketiga berorientasi pada proses dan produk untuk meningkatkan hasil belajar salah satu hal penting adalah memperhatikan proses belajar mengajar. Keempat, berorientasi pada perubahan mental.Setiap aktifitas pendidikan, sesuatu yang harus menjadi perhatian utama adalah hasil yang ingin dicapai yaitu tujuan dan target pendidikan dan akhlakul karimah sebagai porsi paling penting dalam pendidikan Islam (Noor \& Sikand, 2008).

Total Quality Management dalam pendidikan adalah filosofi perbaikan terus menerus dimana lembaga pendidikan menyediakan seperangkat sarana atau alat untuk memenuhi bahkan melampaui kebutuhan, keinginan dan harapan steakholder saat ini dan dimasa mendatang (Jabbar \& Hussin, 2019). Dalam dunia pendidikan madrasah yang bermutu adalah madrasah yang menetapkan keberhasilan pada proses, out put, dan out come. Jika mutu pendidikan ingin dicapai maka siswa, guru, staf dan masyarakat harus bekerjasama untuk mewujudkan tujuan (Noor \& Sikand, 2008). Dalam meningkatkan mutu pendidikan, maka kita harus memperhatikan mengenai beberapa, Komponen-komponen: a) Siswa dan Guru b) Kurikulum c) Sarana dan prasarana pendidikan d) Pengelolaan madrasah, meliputi pengelolaan kelas, guru, siswa, sarana dan prasarana, peningkatan tata tertib dan kepemimpinan e) Pengelolaan proses pendidikan, meliputi penampilan guru, penguasaan materi, serta penggunaan strategi pendidikan f) Pengelolaan dana g) Evaluasi h) Kemitraan, meliputi hubungan madrasah dengan lembaga lain.

Peningkatan mutu madrasah menurut Sudarwan Danim (2013) melibatkan lima faktor: 1. Kepemimpinan Kepala madrasah yang efektif 2. Siswa, "anak sebagai pusat "sehingga kompetensi dan kemampuan siswa dapat digali 3. Pelibatan guru secara maksimal. 4. Kurikulum yang tetap tetapi dinamis, sehingga tujuan mutu dapat dicapai 5. Jaringan kerjasama tidak hanya terbatas pada lingkungan madrasah dan masyarakat tetapi dengan organisasi lain, seperti perusahaan/instansi 6. Pimpinan dan karyawan harus menjadi satu tim yang utuh (team-work) yang saling membutuhkan dan saling mengisi kekurangan yang ada sehingga target (goals) akan tercipta dengan baik. Untuk peningkatan aktivitas dan kreatifitas peserta didik, peningkatan disiplin belajar, kepala sekolah harus menerapkan beberapa langkah berikut ini : 1) Peningkatan aktivitas dan kreatifitas peserta didik, proses pendidikan pada hakekatnya untuk mengembangkan aktifitas dan kreatifitas peserta didik melalui berbagai interaksi peserta didik; 2) Peningkatan disiplin belajar, disiplin madrasah dapat diartikan sebagai keadaan tertib dimana guru, staf madrasah dan peserta didik bergabung dalam madrasah, tunduk kepada peraturan yang telah ditetapkan dengan senang hati; 3) Peningkatan motivasi belajar, mulyasa (2005) menyebutkan bahwa peserta didik akan belajar dengan sungguh-sungguh apabila memiliki motivasi. Dalam kaitannya dengan ini guru dituntut untuk memiliki kemampuan untuk membangkitkan motivasi belajar peserta didik sehingga dapat mencapai tujuan belajar. 


\section{Kebijakan Peningkatan Mutu Pendidikan}

Saleh (2004) menjelaskan bahwa dalam usaha menerapkan peningkatan mutu pendidikan nasional adalah melalui berbagai pelatihan dan peningkatan kompetensi, pengadaan buku dan alat pelajaran, perbaikan sarana dan prasarana pendidikan, dan peningkatan mutu manajemen pendidikan. Ada beberapa komponen yang dapat meningkatkan mutu pendidikan, diantaranya adalah : (a). Proses pendidikan; Pikiran utama yang terdapat dalam prinsip, strategi, dan tahapan belajar mengajar mencerminkan bahwa pendidikan tidak sesederhana dengan proses penyampaiannya. (b). Prosedur pendidikan. Pengembangan kegiatan belajar mengajar harus diorientasikan pada fitrah manusia agar terwujud keseimbangan.

Pendekatan pendidikan, yang dapat ditempuh oleh Kepala Sekolah antara lain adalah ; 1) Pendekatan rasional, pendekatan pendidikan yang lebih menekankan pada aspek penalaran; 2) Pendekatan emosional, yakni upaya menggugah perasaan (emosi) peserta didik dalam menghayati perilaku yang sesuai dengan ajaran agama dan budaya bangsa; 3) Pendekatan pengalaman, yakni memberikan kesempatan kepada peserta didik untuk mempraktekkan dan merasakan hasil-hasil pengalaman ibadah dalam menghadapi tugas-tugas dan masalah-masalah dalam kehidupan; 4) Metode, Metode apapun yang digunakan oleh pendidik dalam proses pendidikan harus disesuaikan dengan materi yang akan diajarkan; 5) Kurikulum Pengembangan kurikulum harus dapat mengakomodasikan unsur-unsur teoritis dan praktis berdasarkan tujuan yang berdasarkan kebutuhan yang diperkirakan sesuai dengan dinamika yang beraneka ragam; 6) Kerja pendidikan, Kerja pendidikan ini bagi pendidik dimaksudkan untuk meningkatkan pelayanan terhadap mutu pendidikan secara team teaching di kelas dan team working dalam workshop; 7) Peran pendidik Tiga komponen kompetensi yang harus dimiliki guru agar kegiatan pendidikan yang dilakukan bisa berjalan dengan efektif : (a). Komponen kompetensi pengelolaan pendidikan yang meliputi: penyusunan rencana pendidikan, pelaksanaan interaksi belajar mengajar, penilaian prestasi belajar peserta didik, pelaksanaan tindak lanjut peserta didik. (b). Komponen kompetensi pengembangan potensi yaitu pengembangan profesi. (c). Komponen kompetensi penguasaan akademik yang meliputi: pemahaman wawasan pendidikan, dan penguasaan bahan kajian; 8) Pengelolaan siswa/pendekatan "anak sebagai pusat" (the child-centered approach). Filosofi pendidikan berpusat pada siswa adalah penekanan lebih pada proses pendidikan secara signifikan ketimbang produk/outcomes pendidikan. Pada pendekatan ini lebih menitik beratkan pada: (a). Anak adalah sentral pelaksanaan pendidikan; (b). Pendidikan berfokus pada anak secara total; (c). Guru memberi peluang bagi anak untuk secara alami mengembangkan diri hingga ke tingkat edvan; (d). Sentral perubahan terhadap anak meski tidak selalu diobservasi; (e). Perubahan hanya dialami pada konteks dari siswa secara menyeluruh; (f). Perubahan dan motivasi anak bersifat internal, guru hanya member dorongan dan fasilitas (Sudarwan Danim, 2006); 9) Pengelolaan lingkungan kelas, Iklim belajar yang kondusif merupakan faktor pendorong yang dapat memberikan daya tarik terhadap proses pendidikan, sebaliknya iklim belajar yang kurang menyenangkan akan menimbulkan kejenuhan dan rasa bosan.

\section{Kepemimpinan Kepala Sekolah}

Kepemimpinan menurut Kamus Besar Bahasa Indonesia berasal dari kata dasar "pimpin" dengan mendapat awalan menjadi "memimpin" maka diartikan menuntun, menunjukkan jalan dan membimbing dalam perkataan ini dapat disamakan pengertiannya dengan mengetahui, mengepalai, memandu dan melatih dalam arti mendidik dan mengajari supaya dapat mengerjakan sendiri (Pramudyo, 2010).।

Ngalim Poerwanto (2003) mendefinisikan kepemimpinan adalah tindakan atau perbuatan diantara perorangan dan kelompok yang menyebabkan seseorang atau kelompok maju ke arah tujuan tertentu. Kepemimpinan merupakan proses mempengaruhi aktivitas individu atau kelompok dalam usaha ke arah pencapaian tujuan dalam situasi tertentu (Notoatmojo, 2011; Pfeffer, 2015). Dengan kata lain dalam proses kepemimpinan itu dijumpai fungsi kepemimpinan, pengikut (anggota), dan situasi. Sedangkan Kepala sekolah merupakan motor penggerak, penentu arah kebijakan sekolah yang akan menentukan bagaimana tujuan-tujuan dan pendidikan pada umumnya direalisasikan bagaimana (Mulyasa, 2003).

Menurut Slamet ada 17 ciri kepala sekolah yang tangguh. Ke tujuh belas ciri tersebut adalah memiliki (1) visi-misi dan strategi (2) kemampuan mengkoordinasikan dan menyerasikan sumberdaya (3) kemampuan mengambil keputusan (4) toleransi terhadap perbedaan setiap orang (5) memobilisasi sumber daya (6) menerangi musuh-musuh kepala sekolah (7) menggunakan input manajemen (9) menjalankan perannya yang berdimensi banyak seperti pemimpin, manajer pendidikan dan lainlain, (10) melaksanakan dimensi-dimensi tugas, proses, lingkungan dan ketrampilan personal (11) menjalankan gejala empat serangkai yaitu merumuskan sasaran, melakukan analisis SWOT, dan mengupayakan langkah-langkah 
untuk meniadakan persoalan , (12) menggalang team work yang cerdas dan kompak (13) mendorong kegiatan-kegiatan kreatif (14) menciptakan sekolah belajar (15) menerapkan manajemen berbasis sekolah (16) memusatkan perhatian pada pengelolaan proses belajar mengajar dan (17) memperdayakan sekolah (Slamet, 2002).

Dalam satuan pendidikan, menduduki dua jabatan penting untuk bisa menjamin kelangsungan proses pendidikan sebagaimana yang telah digariskan oleh peraturan perundang-undangan. Pertama, kepala sekolah dalam pengelola pendidikan di sekolah secara keseluruhan. Kedua, Kepala Sekolah adalah pemimpin formal di sekolahnya (Lauen, D \& Gaddis, 2016; Widodo, 2016).

Pemimpin harus mampu mengantisipasi perubahan yang terjadi secara tiba-tiba, dapat mengoreksi kelemahan-kelemahan, dan sanggup membawa organisasi kepada sasaran dalam jangka waktu yang telah ditetapkan. Jadi, bisa dikatakan bahwa kepemimpinan merupakan kunci kesuksesan sebuah organisasi. Di samping itu, dalam setiap kerja kolektif dibutuhkan pemimpin untuk mengefisienkan setiap langkah dari kegiatan tersebut (Hidayat \& Machali, 2018; Muazza, Mukminin, Habibi, Hidayat, \& Abidin, 2018).

Kepala sekolah sebagai pemimpin seharusnya dalam praktek sehari hari selalu berusaha memperhatikan dan mempraktekkan tujuh fungsi kepemimpinan di dalam kehidupan sekolah (Irmayani et al., 2018). Mulyasa (2003) menjelaskan bahwa dalam paradigma baru manajemen pendidikan, kepala sekolah sedikitnya harus mampu berfungsi sebagai educator, administrator, supervisor, leader, innovator, dan motivator: 1) kepala sekolah sebagai edukator (pendidik); 2) kepala sekolah sebagai manajer; 3) kepala sekolah sebagai administrator; 4) kepala sekolah sebagai supervisor; 5) kepala sekolah sebagai leader; 6) kepala sekolah sebagai inovator; 7) kepala sekolah sebagai motivator

Adapun yang menjadi tugas-tugas pokok/wewenang kepala sekolah mencakup 7 (Mahardhani, 2015): 1) Bidang akademik yang berkenaan dengan proses belajar mengajar di dalam dan di luar madrasah, (menyusun program catur wulan/semesteran dan program tahunan, terutama juga pembagian tugas mengajar, menyusun jadwal pelajaran setiap tahu, mengatur pelaksanaan penyusunan model satuan pelajaran dan pembagian waktu yang digunakan); 2) Bidang ketatausahaan dan keuangan sekolah (menyelenggarakan surat menyurat, mengatur penerimaan keuangan, mengelola penggunaan keuangan dan mempertanggungjawabkan keuangan); 3) Bidang kesiswaaan (mengatur penerimaan murid berdasarkan peraturan penerimaan murid baru, mengatur program bimbingan dan penyuluhan, mencatat kehadiran dan ketidakhadiran guru/murid); 4) Bidang personalia:(menginventarisasi personalia, mengusulkan formasi guru dan merencanakan pembagian tugas-tugas guru, termasuk menghitung beban kerja guru); 5) Bidang gedung dan perlengkapan sekolah (mengatur pemeliharaan kebersihan gedung dan keindahan halaman sekolah, pengadaan dan pemeliharaan perlengkapan sekolah, menyelenggarakan inventarisasi tanah, gedung dan perlengkapan sekolah, baik yang habis dipakai maupun yang permanen); 6 ) Bidang peralatan pelajaran (mengatur buku-buku pelajaran untuk pegangan guru dan murid, mengatur perpustakaan guru/murid, mengatur alat-alat pelajaran/peraga tiap bidang studi); 7) Bidang sekolah dan masyarakat: (menyelenggarakan pembentukan dan secara kontinyu berhubungan dengan BP3 menerima dan memberikan pelayanan pada tamu, mewakili sekolah dalam hubungan kerja dengan pihak luar); 8) Kepala Sekolah Sebagai Supervisor, supervisi adalah pembinaan guru, maka pengertian supervisi secara terminologi sering diartikan sebagai serangkaian usaha bantuan kepada guru terutama bantuan yang berwujud layanan profesional yang dilakukan oleh kepala sekolah, penilik sekolah dan pengawas serta pembina lainnya untuk meningkatkan proses dan hasil belajar (Alnizar, 2019; Demewoz \& Abebe, 2018; Fitri, Erwinda, \& Ifdil, 2018).

Sebagai pemimpin pendidikan dan pengajaran, akan selalu berhadapan dengan kenyataan-kenyataan yang ada, yaitu tentang sukses atau tidaknya kegiatan pembinaan, bimbingan dan layanan yang dapat diusahakan (Goodill, 2017; Uotila, Harmaakorpi, \& Hermans, 2013).

\section{Kesimpulan}

Manajemen Kebijakan Kepala Madrasah dalam meningkatkan mutu pendidikan di Madrasah Ibtidaiyah Negeri 1 Rejang Lebong adalah dengan menerapkan (1). Kebijakan Kepala Madrasah dengan memprioritaskan madrasah dalam pengembangan kurikulum dan pengembangan profesionalitas guru melalui kegiatan Kelompok Kerja Guru (KKG). (2). Kebijakan kepala Madrasah dilakukan melalui faktor internal dan eksternal Madrasah sehingga dapat meningkatkan mutu pendidikan di Madrasah Ibtidaiyah Negeri 1 Rejang Lebong: menumbuhkan sikap jujur guru, penghargaan, iklim komunikasi demokrasi 
yang serasi dan manusiawi dalam lingkungan sekolah. (3). Kepala sekolah menumbuhkan suasana Madrasah yang kondusif, menumbuhkan rasa tanggungjawab kepada guru dalam mengajar, sehingga melalui koordinasi dengan pimpinan kabupaten, komite madrasah dan masyarakat, sehingga mutu pendidikan dapat meningkat.

\section{Acknowledgment}

Ucapan terimakasih penulis sampaikan kepada Bapak Dr. Rahmad Hidayat, M.Ag., M.Pd selaku Rektor IAIN Curup yang telah mengizinkan penulis melakukan penelitian ditengah aktifitas kampus yang begitu padat, dan bantuan pendanaan dari Kementerian Agama RI, penulis mengucapkan ribuan terimakasih atas kesempatan penelitian ini, semoga penelitian yang terbit di Jurnal Konseling dan Pendidikan ini dapat menjadi khazanah ilmu pengetahuan dan pengembangan kelembagaan Madrasah di Rejang Lebong dan secara luas di Provinsi Bengkulu.

\section{Referensi}

Akinyemi, G. M., \& Abiddin, N. Z. (2013). Quality administration and management in higher education in nigeria: Implications for human resource development. International Education Studies, 6(4), 225235. https://doi.org/10.5539/ies.v6n4p225

Alnizar, F. (2019). Mass Rallies : An Overview of Santri Rejection on the Five-day School Policy in Indonesia. Jurnal Pendidikan Islam, 8(June), 51-68. https://doi.org/10.14421/jpi.2019.81.51-68

Amin, M., Arsil, Fathurrochman, I., Bahri, S., \& Rahmaningsih, S. (2019). Manajemen Mutu Pendidikan Pada Perguruan Tinggi (1st ed.). Rejang Lebong: LP2 IAIN Curup.

Beerkens, M. (2018). Evidence-based policy and higher education quality assurance: progress, pitfalls and promise. European Journal of Higher Education, 8(3), 272-287. https://doi.org/10.1080/21568235.2018.1475248

Davis, A. (2017). Managerialism and the risky business of quality assurance in universities. Quality Assurance in Education, 25(3), 317-328. https://doi.org/10.1108/QAE-06-2016-0027

Demewoz, E., \& Abebe, F. (2018). Investigating the tourism potential of Gafat industrial village: South Gondar administrative zone, North Western Ethiopia. African Journal of Hospitality, Tourism and Leisure, 7(4), 1-15.

Fathurrochman, I. (2017). Pengembangan kompetensi pegawai aparatur sipil negara (ASN) Sekolah Tinggi Agama Islam Negeri (STAIN) Curup. Manajer Pendidikan, 11(21), 120-129.

Fathurrochman, I., Budiman, D. A., Alamsyahril, \& Kristiawan, M. (2019). Revitalization Management Of Islamic Boarding School Preventing The Radicalism. Restaurant Business, (10), $495-505$. Retrieved from https://journals.eduindex.org/index.php/rb/article/view/9462

Fitri, E., Erwinda, L., \& Ifdil, I. (2018). Konsep Adiksi Game Online dan Dampaknya terhadap Masalah Mental Emosional Remaja serta Peran Bimbingan dan Konseling. Jurnal Konseling Dan Pendidikan, 6(2), 211-219. https://doi.org/10.29210/127200

Goodill, C. . (2017). An Analysis of the Educational System In Finland and the United States: A Case Study.

Hidayat, A., \& Machali, I. (2018). The Handbook of Education Management (2nd ed.). Jakarta: Prenadamedia Group.

Hou, A. Y. C., Kuo, C. Y., Chen, K. H. J., Hill, C., Lin, S. R., Chih, J. C. C., \& Chou, H. C. (2018). The implementation of self-accreditation policy in Taiwan higher education and its challenges to university internal quality assurance capacity building. Quality in Higher Education, 24(3), 238-259. https://doi.org/10.1080/13538322.2018.1553496

Irmayani, H., Wardiah, D., \& Kristiawan., M. (2018). The strategy of SD Pusri in improving educational quality. International Journal of Scientific and Technology Research, 7(7), 113-121.

Istiningtyas, L., \& Lukmawati, L. (2019). Tracer study of the psychology faculty of UIN Raden Fatah Palembang in 2018: satisfaction of alumni and stakeholders on the implementation of Islamic psychology study programs. Jurnal Konseling Dan Pendidikan, $7(1), \quad 8$. https://doi.org/10.29210/129200

Jabbar, M. N., \& Hussin, F. (2019). Quality management as a strategic tool to enhance the relationship between leaders' behavior and lecturers' job satisfaction. International Journal of Higher Education, 8(3), 36-46. https://doi.org/10.5430/ijhe.v8n3p36 
Khasanah, U. (2014). Manajemen Program Adiwiyata Di SMP Negeri 2 Baturraden Banyumas.

Kristiawan, M. (2016). Telaah Revolusi Mental Dan Pendidikan Karakter Dalam Pembentukkan Sumber Daya Manusia Indonesia Yang Pandai Dan Berakhlak Mulia. Ta'dib, 18(1), 13-25. Retrieved from http://ecampus.iainbatusangkar.ac.id/ojs/index.php/takdib/article/view/274

Kusumawati, M. P. (2019). Harmonisasi Antara Etika Publik Dan Kebijakan Publik. Jurnal Yuridis, 6(1), 1. https://doi.org/10.35586/jyur.v6i1.794

Lauen, D, L., \& Gaddis, S. . (2016). Accountability Pressure, Academic Standards, and Educational Triage. Educatinal Evaluation and Policy Analysis, 38(1), 127-147.

Mahardhani, A. J. (2015). Kepemimpinan ideal kepala sekolah. Jurnal Dimensi Pendidikan Dan Pembelajaran, 3(2), 1-4.

Manap, S. (2013). Perencanaan Pendidikan (1st ed.). Bogor: PT Penerbit IPB Press.

Mardlotillah, F. (2013). Implementasi Kebijakan Sekolah dalam Upaya Pengembangan Pendidikan Karakter melalui Program Pembiasaan Membaca Al-Qur'an. Jurnal Kebijakan Dan Pengembangan Pendidikan, 1(2), 150-155.

Muazza, M., Mukminin, A., Habibi, A., Hidayat, M., \& Abidin, A. (2018). Education in Indonesian islamic boarding schools: Voices on curriculum and radicalism, teacher, and facilities. Islamic Quarterly, 62(4), 507-536.

Murfi, A. (2014). Bias Gender dalam Buku Teks Pendidikan Agama Islam dan Kristen. Jurnal Pendidikan Islam, 3(2), 267. https://doi.org/10.14421/jpi.2014.32.267-288

Ngalim, P. (2007). Administrasi dan Supervisi. 1-8.

Noor, F. A., \& Sikand, Y. (2008). The Madrasa in Asia Political Activism and Transnational Linkages (1st ed.; M. van Bruinessen, Ed.). Amsterdam: Amsterdam University Press.

Notoatmojo, S. (2011). Pengembangan Sumber Daya Manusia. Jurnal LPPM Bidang EkoSosBudKum, 2(1), 124.

Pemerintah Republik Indonesia. (2005). Undang-Undang Republik Indonesia, Tentang Guru dan Dosen. Retrieved from http://sumberdaya.ristekdikti.go.id/wp-content/uploads/2016/02/uu-nomor-14tahun-2005-ttg-guru-dan-dosen.pdf

Pfeffer, F. T. (2015). Equality and Quality in Education a Comparative Study of 19 Countries. Social Science Research, 51(1), 350-368. https://doi.org/10.1016/j.ssresearch.2014.09.004

Pramudyo, A. (2010). Analisis Faktor-Faktor Yang Mempengaruhi Kinerja Dosen Negeri Pada Kopertis Wilayah V Yogyakarta. Jurnal Bisnis : Teori Dan Implementasi, 1(1), 1-11. Retrieved from http://journal.umy.ac.id/index.php/bti/article/view/2407

Pretorius, L., \& Macaulay, L. (2019). Wellbeing in Doctoral Education. In Wellbeing in Doctoral Education. https://doi.org/10.1007/978-981-13-9302-0

Ramdhani, A., \& Ramdhani, M. A. (2017). Konsep Umum Pelaksanaan Kebijakan Publik. Jurnal Publik, 1-12. https://doi.org/10.1109/ICMENS.2005.96

Ristianti, D. H., Danim, S., Winarto, H., \& Dharmayana, I. W. (2019). The Development Of Group Counselling Assessment Instruments. International Journal of Scientific \& Technology Research, 8(10), 267-272. Retrieved from http://www.ijstr.org/paper-references.php?ref=IJSTR-1019-23814

Rusandi, M. A., Sugiharto, D. Y. P., \& Sunawan, S. (2019). Effectiveness of solution-focused group counseling to improve planned happenstance skills of student. Jurnal Konseling Dan Pendidikan, 7(1), 30. https://doi.org/10.29210/127600

Sadler, D. R. (2017). Academic achievement standards and quality assurance. Quality in Higher Education, 23(2), 81-99. https://doi.org/10.1080/13538322.2017.1356614

Salto, D. J. (2018). Quality assurance through accreditation: When resistance meets over-compliance. Higher Education Quarterly, 72(2), 78-89. https://doi.org/10.1111/hequ.12151

Torabi, M., Drahansky, M., Paridah, M. ., Moradbak, A., Mohamed, A. ., Owolabi, F. abdulwahab taiwo, ... Abdul Khalid, S. H. . (2016). Pedagogy of the Twenty-First Century: Innovative Teaching Methods. Intech, i(tourism), 13. https://doi.org/http://dx.doi.org/10.5772/57353

Uotila, T., Harmaakorpi, V., \& Hermans, R. (2013). Finnish Mosaic of Regional Innovation System Assesment of Thematical Regional Inovation Platforms Based on Related Variety. European Planning Studies, 20(10), 1583-1602.

Widodo, H. (2016). Potret Pendidikan di Indonesia dan Kesiapannya dalam Menghadapi Masyarakat Ekonomi Asia (MEA). Cendekia: Journal of Education and Society, 13(2), 293. https://doi.org/10.21154/cendekia.v13i2.250 